\title{
MODEL MATEMATIKA PENYEBARAN HIV/AIDS PADA PENGGUNA NARKOBA MELALUI JARUM SUNTIK
}

\author{
Isnaini Mahuda \\ Universitas Bina Bangsa \\ Email: isnainimahuda@binabangsa.ac.id
}

\begin{abstract}
Drug users using needles has become vulnerable communities infected with HIV/AIDS. The use of needle alternately among drug users becomes a way in the spread of the virus. The purpose of this study is to make mathematical model the spread of HIV/AIDS among drug users using needle. The mathematical model constructed consists of two populations, namely drug population and needle population. The population of drug users is divided into four compartments, namely the population of drug users susceptible, exposed, infected, and AIDS while the population of needle is divided into two compartments, namely the population of susceptible and infected syringes. From the results of the analysis of the model, two equilibrium points are obtained, namely the disease-free equilibrium point and the endemic equilibrium point, and the stability analysis is carried out. Basic Reproduction Ratio as the threshold of an outbreak is obtained by finding the greatest characteristic value of the Next generation Matrix (NGM). In this study also carried out numerical simulations to see the dynamics of drug user populations and needle populations then conducted a sensitivity analysis to determine the parameters that most influence the spread of HIV / AIDS in drug users using needle.
\end{abstract}

Keywords: Mathematical model, HIV/AIDS, needle

\begin{abstract}
ABSTRAK
Pengguna narkoba melalui jarum suntik menjadi komunitas yang rawan terinfeksi HIV/AIDS. Penggunaan jarum suntik secara bergantian di kalangan pengguna narkoba menjadi jalan dalam penyebaran virus. Penelitian ini bertujuan untuk memodelkan penyebaran HIV/AIDS di kalangan pengguna narkoba melalui media jarum suntik secara matematis. Model matematika yang dikonstruksi terdiri dari 2 populasi yaitu populasi pengguna narkoba dan populasi jarum suntik. Populasi pengguna narkoba dibagi menjadi 4 kompartemen yaitu populasi pengguna narkoba susceptible, exposed, infected dan AIDS sedangkan populasi jarum suntik dibagi menjadi 2 kompartemen yaitu populasi jarum suntik susceptible dan infected. Dari hasil analisis model diperoleh 2 titik kesetimbangan yaitu titik kesetimbangan bebas penyakit dan titik kesetimbangan endemik kemudian dilakukan analisis kestabilannya. Basic Reproduction Rasio sebagai ambang batas suatu wabah penyakit diperoleh dengan cara mencari nilai karakteristik terbesar dari polinom karakteristik Next Geration Matriks (NGM). Pada penelitian ini juga dilakukan simulasi numerik untuk melihat dinamika populasi pengguna narkoba dan populasi jarum suntik kemudian dilakukan analisis sensitivitas untuk menentukan parameter yang paling mempengaruhi penyebaran HIV/AIDS pada pengguna narkoba melalui jarum suntik.
\end{abstract}

Kata kunci: Model Matematika, HIV/AIDS, Jarum Suntik 


\section{PENDAHULUAN}

HIV atau Human Immunodifiency Virus merupakan penyakit yang disebabkan oleh virus yang menyerang sistem kekebalan tubuh sehingga mengakibatkan imunitas tubuh menjadi berkurang. Seseorang yang positif terinfeksi HIV dalam jangka waktu lima hingga sepuluh tahun kemudian orang tersebut akan mengidap AIDS (Acquired Immunodeficiendy Syndrome). Endemi HIV ini masih menjadi masalah serius di dalam dunia kesehatan. Di Indonesia, pada tahun 2014 menunjukkan bahwa HIV/AIDS sudah menyebar di 386 kabupaten/kota diseluruh provinsi di Indonesia dengan jumlah manusia terinfeksi $H I V$ sebanyak 150.296 orang, dan jumlah manusia terserang penyakit AIDS sebanyak 55.799 orang (Depkes R1, 2014).

Penularan HIV dapat terjadi disebabkan oleh beberapa hal diantaranya yaitu melakukan hubungan seks baik itu heteroseksual ataupun homoseksual dengan penderita HIV, kontak langsung dengan darah penderita HIV, transmisi perinatal dan pemakaian jarum suntik secara bergantian di kalangan pengguna narkoba. Berdasarkan faktor resiko penularan HIV dominan terjadi pada heteroseksual dan pemakaian jarum suntik secara bergantian di kalangan pengguna narkoba (infoDATIN, 2014).

Pemodelan matematika penting digunakan untuk menganalisis penularan HIV/AIDS. Pemodelan matematika merupakan suatu cara untuk dapat membantu memahami suatu fenomena nyata melalui abstraksi masalah. Pemodelan matematika seputar penyebaran HIV/AIDS telah banyak dilakukan. Ram Naresh dan Dilep Sharma (2011) menggunakan model SIA (Susceptible, Infected, AIDS) untuk menganalisis penularan HIV/AIDS secara vertikal dari ibu ke bayinya dan waktu tundaan (time-delay). Selain itu, Setiawaty dkk (2013) juga menganalisis kestabilan model penyebaran HIV/AIDS pada populasi Gay dan perumpuan beresiko rendah. Begitupun penelitian yang dilakukan oleh Triska dan Gusriani (2016) membahas tentang analisis angka reproduksi dasar model matematika penyebaran HIV melalui jarum suntik pada populasi pengguna narkoba. Triska dan Gusriani dalam penelitiannya masih menggunakan model SIA (Susceptible, Infected, AIDS) yang merupakan modifikasi dari model SIR (Susceptible, Infected, Recovery).

Penelitian ini bertujuan untuk mengkonstruksi model matematika pada penyebaran HIV/AIDS pada pengguna narkoba melalui jarum suntik dimana populasinya terdiri dari 2 populasi utama yaitu populasi pengguna narkoba dan populasi jarum suntik. Populasi pengguna narkoba dibagi menjadi 4 kompartemen yaitu populasi penggunan narkoba 
Susceptible, Exposed, Infected dan AIDS sedangkan populasi jarum suntik dibagi menjadi 2 kompartemen yaitu populasi jarum suntik Susceptible dan Infected. Dalam penelitian ini juga akan dianalisis kestabilan dari model dan basic reproduction rasio serta dilakukan simulasi dan analisis sensitivitas untuk melihat parameter yang paling berpengaruh terhadap penyebaran HIV/AIDS pada pengguna narkoba melalui jarum suntik. Dengan demikian, langkah-langkah pencegahan untuk mengurangi penyebaran HIV/AIDS pada pengguna narkoba dengan jarum suntik dapat dilakukan.

\section{METODOLOGI}

Penelitian ini menggunakan teori yang relevan berdasarkan kajian literature. Adapun prosedur yang dilakukan dalam penelitian ini yaitu menetapkan asumsi, mengkonstruksi model transmisi HIV/AIDS pada pengguna narkoba melalui jarum suntik. Dari model yang telah dibuat dicari titik kesetimbangannya kemudian dianalisis kondisi kestabilannya dan menentukan basic reproduction rasio dengan Next Generation Matriks. Selain itu juga dilakukan simulasi dan analisis sensitivitas untuk menentukan parameter yang paling dominan berpengaruh dalam penyebaran HIV/AIDS pada pengguna narkoba melalui jarum suntik.

\section{HASIL DAN PEMBAHASAN}

\subsection{Konstruksi Model}

Pada model ini populasi pengguna narkoba dibagi menjadi 4 kompartemen yaitu $S, E, I$ dan $A$ dimana $S$ adalah populasi pengguna narkoba susceptible, $E$ adalah pengguna narkoba exposed, $I$ pengguna narkoba Infected dan $A$ pengguna narkoba dengan AIDS. Populasi jarum dibagi menjadi 2 kompartemen yaitu $J_{s}$ adalah populasi jarum suntik susceptible dan $J_{i}$ adalah populasi jarum suntik terinfeksi. Secara umum, model matematika penyebaran HIV/AIDS pada pengguna narkoba melalui jarum suntik dapat dilihat pada diagram berikut: 


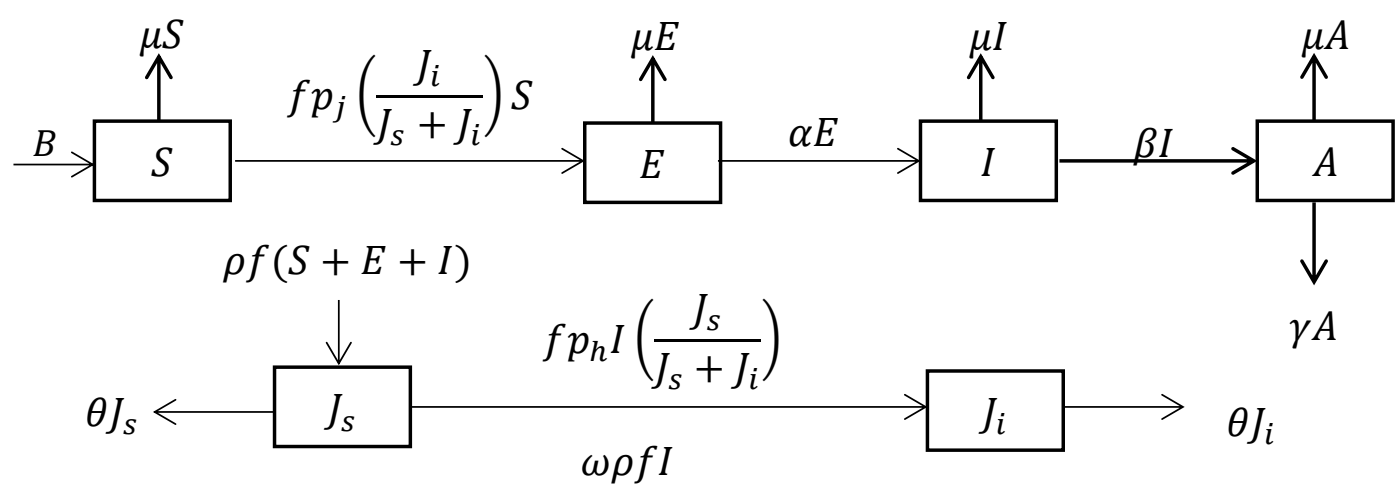

Gambar 1. Diagram transmisi penyebaran HIV/AIDS

Diagram diatas menggambarkan laju perubahan populasi tiap kompartemen. Arah panah masuk menunjukkan pertambahan jumlah populasi dan arah panah keluar menunjukkan pengurangan jumlah populasi. Pada model ini diasumsikan jumlah populasi pada pengguna narkoba dianggap konstan (tidak ada proses migrasi) dan penderita HIV tidak mendapatkan perlakuan antiretroviral.

Model matematika dari diagram tranmisi pada gambar 1 dapat diekspresikan sebagai berikut.

$$
\begin{aligned}
& \frac{d S}{d t}=B-f p_{j}\left(\frac{J_{i}}{J_{s}+J_{i}}\right) S-\mu S . \\
& \frac{d E}{d t}=f p_{j}\left(\frac{J_{i}}{J_{s}+J_{i}}\right) S-(\mu+\alpha) E . \\
& \frac{d I}{d t}=\alpha E-(\mu+\beta) I \\
& \frac{d A}{d t}=\beta I-(\mu+\gamma) A . \\
& \frac{d J_{s}}{d t}=\rho f(S+E+I)-f p_{h} I\left(\frac{J_{s}}{J_{s}+J_{i}}\right)-\theta J_{s}-\omega \rho f I . \\
& \frac{d J_{i}}{d t}=\omega \rho f I+f p_{h} I\left(\frac{J_{s}}{J_{s}+J_{i}}\right)-\theta J_{i} .
\end{aligned}
$$

dengan:

$B$ merupakan laju kelahiran alami dari populasi pengguna narkoba dengan $B>0$ $\mu$ merupakan laju kematian alami dari populasi pengguna narkoba dengan $\mu>0$ $\alpha$ adalah laju transisi dari kompartemen exposed kekompartenen infected $\beta$ adalah laju transisi dari kompartemen infected ke AIDS 
$\theta$ adalah laju kerusakan jarum suntik

$\gamma$ adalah laju kematian akibat AIDS

$f$ adalah frekuensi pengguna narkoba menggunakan jarum suntik

$p_{j}$ adalah peluang infeksi dari jarum terinfeksi ke pengguna narkoba susceptible, dengan $0<p_{j}<1$

$p_{h}$ adalah peluang infeksi dari pengguna narkoba terinfeksi ke jarum suntik susceptible, dengan $0<p_{h}<1$

$\rho$ adalah peluang seorang pengguna narkoba membawa jarum suntik baru dengan $0<$ $\rho<1$

$\omega$ adalah peluang terinfeksi jarum bersih yang dibawa oleh pengguna narkoba yang terinfeksi dengan $0<\omega<1$

\subsection{Menentukan Titik Kesetimbangan}

Titik kesetimbangan diperoleh ketika sistem pada model tidak mengalami perubahan populasi atau $\frac{d S}{d t}=0, \frac{d E}{d t}=0, \frac{d I}{d t}=0, \frac{d A}{d t}=0, \frac{d J_{S}}{d t}=0, \frac{d J_{i}}{d t}=0$ sehingga terdapat dua jenis tititk kesetimbangan pada model ini yaitu titik kesetimbangan bebas penyakit atau $D F E=$ $\left(S, 0,0,0, J_{S}, 0\right)$ dan titik kesetimbangan endemi atau $E N D=\left(S^{*}, E^{*}, I^{*}, A^{*}, J_{S}{ }^{*}, J_{i}{ }^{*}\right)$.

Titik kesetimbangan bebas penyakit dari model diekspresikan sebagai,

$$
D F E=\left(S=\frac{B}{\mu}, 0,0,0, J_{s}=\frac{\rho f B}{\mu \theta}, 0\right)
$$

Titik DFE ini menunjukan bahwa hanya populasi pengguna narkoba susceptible dan jarum susceptible saja yang bernilai positif sedangkan populasi pengguna narkoba yang terinfeksi dan AIDS serta jarum suntik yang terinfeksi bernilai nol.

Adapun titik kesetimbangan endemik dari model diekspresikan sebagai $E N D=$ $\left(S^{*}, E^{*}, I^{*}, A^{*}, J_{S}^{*}, J_{i}^{*}\right)$ dengan,

$$
\begin{aligned}
S^{*} & =\frac{\left(\rho \mu+\rho \beta+\rho \alpha+p_{h} \alpha\right) B}{\alpha\left(p_{h} \mu+p_{h} f p_{j}-\rho \beta+\rho \omega f p_{j}\right)} \\
E^{*} & =\frac{\left(B\left(-\rho \mu^{2}-\rho \mu \beta-\rho \alpha \mu-\rho \alpha \beta+\rho \omega f \alpha p_{j}+p_{h} f \alpha p_{j}\right)\right)}{\left(\left(p_{h} \mu^{2}+p_{h} f p_{j} \mu+\mu p_{h} \alpha-\rho \mu \beta+\rho \omega f p_{j} \mu+\rho \omega f \alpha p_{j}+p_{h} f \alpha p_{n} \alpha \beta\right) \alpha\right)} \\
I^{*} & =\frac{B\left(-\rho \mu^{2}-\rho \mu \beta-\rho \alpha \mu+\rho \omega f \alpha p_{j}+p_{h} f \alpha p_{j}-\rho \alpha \beta\right)}{p_{h} \mu^{3}+a_{1} \mu^{2}+a_{2} \mu+\rho \omega f \alpha p_{j} \beta-\rho \alpha \beta^{2}+p_{h} f \alpha p_{j} \beta} \\
A^{*} & =\frac{\beta B\left(-\rho \mu^{2}-\rho \mu \beta-\rho \alpha \mu+\rho \omega f \alpha p_{n}+p_{h} f \alpha p_{j}-\rho \alpha \beta\right)}{\left(p_{h} \mu^{3}+a_{1} \mu^{2}+a_{2} \mu+\rho \omega f \alpha p_{j} \beta-\alpha \beta^{2}+p_{h} f \alpha p_{j} \beta\right)(\mu+\gamma)}
\end{aligned}
$$


$J_{s}^{*}$

$$
\begin{aligned}
& =\frac{\left(B\left(p_{h} \mu^{2}+a_{3} \mu+a_{4}\right) \rho^{2}\left(\mu^{2}+\left(\alpha+f p_{j}+\beta\right) \mu+\alpha f p_{j}+\alpha \beta-\omega f \alpha p_{j}+p_{j} f \beta\right)\right)}{\left.(\mu+\gamma)(\mu+\beta) a_{5} \theta p_{j}\left(\rho \mu+\rho \alpha+\rho \beta+p_{h} \alpha\right)\right)} \\
& J_{i}{ }^{*}=\frac{\left(B\left(p_{h} \mu^{2}+a_{3} \mu+a_{4}\right) \rho\left(-\rho \mu^{2}+(-\rho \alpha-\rho \beta) \mu+\rho \omega f \alpha p_{j}+p_{h} f \alpha p_{j}-\rho \alpha \beta\right)\right)}{\left(\left(\mu^{3} \rho+a_{6} \mu^{2}+a_{7} \mu+a_{8}\right) p_{j} \theta a_{5}\right.}
\end{aligned}
$$

Dimana,

$$
\begin{aligned}
& a_{1}=p_{h} f p_{j}+p_{h} \alpha-\rho \beta+p_{h} \beta+\rho \omega f p_{j} \\
& a_{2}=\rho \omega f \alpha p_{j}+p_{h} \alpha \beta+p_{h} f \alpha p_{j}-\rho \alpha \beta+p_{h} f p_{j} \beta+\rho \omega f p_{j} \beta-\rho \beta^{2} \\
& a_{3}=\rho \omega f p_{j}+p_{h} f p_{j}+p_{h} \beta+p_{h} \alpha \\
& a_{4}=p_{h} f \alpha p_{j}+\rho \omega f p_{j} \beta+\rho \omega f \alpha p_{j}+p_{h} f p_{j} \beta+p_{h} \alpha \beta \\
& a_{5}=p_{h} \mu+p_{h} f p_{j}-\rho \beta+\rho \omega f p_{j} \\
& a_{6}=2 \rho \alpha+2 \rho \beta+p_{h} \alpha \\
& a_{7}=p_{h} \alpha \beta+3 \rho \alpha \beta+\rho \beta^{2}+\alpha^{2} \rho+p_{h} \alpha^{2} \\
& a_{8}=p_{h} \alpha^{2} \beta+\rho \alpha \beta^{2}+\alpha^{2} \rho \beta
\end{aligned}
$$

Eksistensi titik kesetimbangan endemik terpenuhi ketika populasi pengguna narkoba susceptible, exposed, infected dan AIDS serta populasi jarum suntik susceptible dan infected bernilai positif.

Dengan demikian,

$$
\begin{gathered}
-\rho \mu^{2}-\rho \mu \beta-\rho \alpha \mu+\rho \omega f \alpha p_{j}+p_{h} f \alpha p_{j}-\rho \alpha \beta>0 \\
\rho \omega f \alpha p_{j}+p_{h} f \alpha p_{j}>\rho \mu^{2}+\rho \mu \beta+\rho \alpha \mu+\rho \alpha \beta \\
\frac{\rho \omega f \alpha p_{j}+p_{h} f \alpha p_{j}}{\rho \mu^{2}+\rho \mu \beta+\rho \alpha \mu+\rho \alpha \beta}>1
\end{gathered}
$$

Sehingga eksistensi titik kesetimbangan endemik terpenuhi ketika $R_{0}>1$ dengan,

$$
R_{0}=\frac{\rho \omega f \alpha p_{j}+p_{h} f \alpha p_{j}}{\rho \mu^{2}+\rho \mu \beta+\rho \alpha \mu+\rho \alpha \beta}
$$

\subsection{Analisis Besaran Ambang Batas atau Basic Reproduction Ratio}

Basic Reproductive Ratio biasanya dinotasikan sebagai $R_{0}$ menurut Diekmann (2009) diperoleh dengan cara membangun sebuah matriks yang disebut sebagai Next Geration Matriks (NGM). $R_{0}$ mempunyai nilai ambang batas 1 , artinya jika $R_{0}>1$ maka akan terjadi endemik yang ditandai dengan meningkatnya populasi yang terinfeksi. Namun jika $R_{0}<1$ maka tidak terjadi endemik. Next Generation Matrix dari model dapat diformulasikan sebagai berikut: 


$$
N G M=\left(\begin{array}{ccc}
0 & 0 & \frac{p_{j}}{\rho} \\
\frac{\alpha}{\mu+\alpha} & 0 & 0 \\
0 & \frac{\rho \omega f+p_{h} f}{\mu+\beta} & 0
\end{array}\right)
$$

Polinom karakteristik untuk menemukan $R_{0}$ dari NGM dapat ditulis sebagai berikut:

$$
F(\lambda)=\lambda^{3}(\mu+\alpha) \rho(\mu+\beta)-\alpha p_{j} f\left(\rho \omega+p_{h}\right)
$$

Dengan demikian diperoleh $R_{0}$ sebagai nilai eigen terbesar dari polinom karakteristik matriks $N G M$ yaitu

$$
R_{0}=\sqrt[3]{\frac{\alpha p_{j} f\left(\rho \omega+p_{h}\right)}{(\mu+\alpha) \rho(\mu+\beta)}}=\sqrt[3]{\frac{\rho \omega f \alpha p_{j}+p_{h} f \alpha p_{j}}{\rho \mu^{2}+\rho \mu \beta+\rho \alpha \mu+\rho \alpha \beta}}
$$

\subsection{Analisis Kestabilan Titik Kesetimbangan}

Kestabilan titik kesetimbangan bebas penyakit dapat ditentukan berdasarkan nilai karakteristik dari matriks Jacobi sistem. Pelinearan model disekitar titik kesetimbangan bebas penyakit.

$$
D F E=\left(S, E, I, A, J_{S}, J_{i}\right)=\left(S, 0,0,0, J_{S}, 0\right)=\left(\frac{B}{\mu}, 0,0,0, \frac{\rho f B}{\mu \theta}, 0\right)
$$

Menghasilkan matriks Jacobi:

$$
J a c=\left(\begin{array}{cccccc}
-\mu & 0 & 0 & 0 & 0 & -\frac{p_{j} \theta}{\rho} \\
0 & -\mu-\alpha & 0 & 0 & 0 & \frac{p_{j} \theta}{\rho} \\
0 & \alpha & -\mu-\beta & 0 & 0 & 0 \\
0 & 0 & \beta & -\mu-\gamma & 0 & 0 \\
\rho f & \rho f & \rho f-\rho \omega f-p_{h} f & 0 & -\theta & 0 \\
0 & 0 & \rho \omega f+p_{h} f & 0 & 0 & -\theta
\end{array}\right)
$$

Nilai karakteristik dari matriks Jacobi diatas adalah:

$$
\lambda_{1}=-\mu, \lambda_{2}=-\theta \text { dan } \lambda_{3}=-(\mu+\gamma)
$$

sedangkan $\lambda_{4}, \lambda_{5}, \lambda_{6}$ merupakan akar-akar dari persamaan berikut,

$$
\lambda^{3} \rho+\rho b_{1} \lambda^{2}+\rho b_{2} \lambda-\theta b_{3}
$$

Dimana,

$$
\begin{aligned}
& b_{1}=\theta+2 \mu+\alpha+\beta \\
& b_{2}=2 \theta \mu+\mu^{2}+\theta \alpha+\theta \beta+\beta \mu+\alpha \mu+\alpha \beta
\end{aligned}
$$




$$
b_{3}=-\rho \mu^{2}-\rho \mu \beta-\rho \alpha \mu+\rho \omega f \alpha p_{j} \theta \alpha+p_{h} f \alpha \theta p_{j}-\rho \alpha \beta
$$

Titik kesetimbangan bebas penyakit akan bersifat stabil jika semua akar dari polinom karakteristik dari matriks Jacobi bernilai negatif. Dari polinom tersebut dapat diketahui bahwa syarat agar titik kesetimbangan ini stabil adalah $b_{3}<0$,

$$
\begin{gathered}
b_{3}=-\rho \mu^{2}-\rho \mu \beta-\rho \alpha \mu+\rho \omega f \alpha p_{j} \alpha+p_{h} f \alpha p_{j}-\rho \alpha \beta<0 \\
\rho \omega f \alpha p_{j} \alpha+p_{h} f \alpha p_{j}<\rho \mu^{2}+\rho \mu \beta+\rho \alpha \mu+\rho \alpha \beta \\
\frac{\rho \omega f \alpha p_{j} \alpha+p_{h} f \alpha p_{j}}{\rho \mu^{2}+\rho \mu \beta+\rho \alpha \mu+\rho \alpha \beta}<1
\end{gathered}
$$

Sehingga titik kesetimbangan bebas penyakit bersifat stabil ketika $R_{0}<1$, dengan,

$$
R_{0}=\frac{\rho \omega f \alpha p_{j} \alpha+p_{h} f \alpha p_{j}}{\rho \mu^{2}+\rho \mu \beta+\rho \alpha \mu+\rho \alpha \beta}
$$

\subsection{Simulasi Numerik dan Analisis Sensitivitas}

Untuk keperluan simulasi diasumsikan nilai-nilai parameter sebagai berikut:

Tabel 1. Parameter dan nilai Simulasi

\begin{tabular}{clcl}
\hline Parameter & Nilai & Parameter & Nilai \\
\hline$B$ & 0,29397 & $f$ & 2 \\
$\mu$ & $4,2145 \times 10^{-4}$ & $p_{j}$ & 0,001 \\
$\alpha$ & $5,4795 \times 10^{-2}$ & $p_{h}$ & 0,65 \\
$\beta$ & $2,7397 \times 10^{-3}$ & $\rho$ & 0,15 \\
$\theta$ & 0,33333 & $\omega$ & 0,75 \\
$\gamma$ & $1,3699 \times 10^{-2}$ & & \\
\hline
\end{tabular}

Adapun populasi awal dari tiap kompartemen dipilih nilai-nilai yang secara matematis dapat dituliskan sebagai berikut.

$$
S(0)=1500, E(0)=1000, I=500, A(0)=100, J_{s}(0)=500, J_{i}(0)=100 .
$$

Hasil dari simulasi numerik terlihat pada gambar 2 berikut:

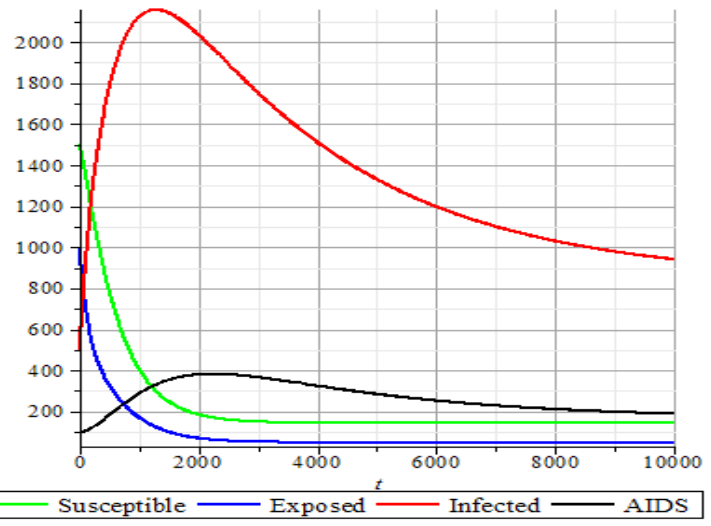

Gambar 2 (a)

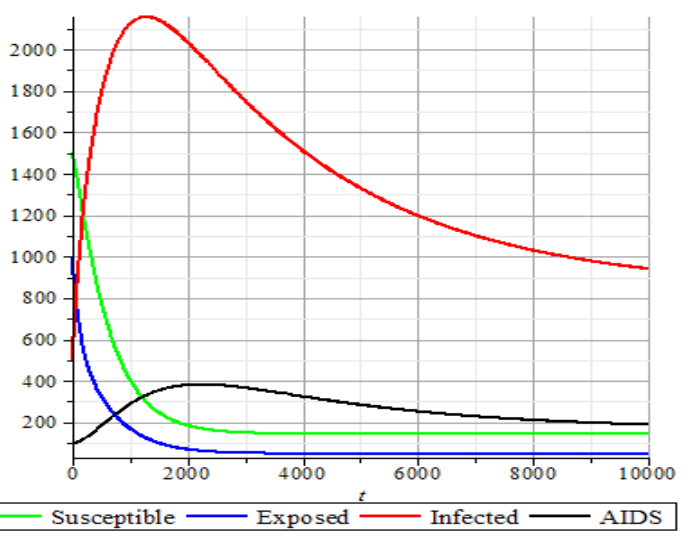

Gambar 2 (b) 
Hasil simulasi ini menggambarkan dinamika setiap populasi baik pada populasi pengguna narkoba maupun populasi jarum suntik. Pada gambar 2(a) menunjukkan bahwa populasi pengguna narkoba susceptible dan exposed mengalami penurunan sedangkan pada populasi pengguna narkoba infected dan AIDS mengalami peningkatan hingga mencapai puncaknya kemudian menurun dan pada jangka waktu yang cukup lama populasinya akan stabil pada jumlah tertentu. Begitupun pada populasi jarum suntik, pada gambar 2(b) memperlihatkan bahwa populasi jarum suntik susceptible mengalami penurunan sedangkan populasi jarum suntik infected mengalami peningkatan hingga pada titik tertentu jumlahnya menurun kemudian stabil. Jika disubstitusi nilai-nilai parameter yang digunakan pada simulasi ini maka akan diperoleh nilai $R_{0}=3,171990416>1$ sehingga terjadi endemik yang ditandai dengan meningkatnya populasi yang terinfeksi.

Analisis sensitivitas dilakukan untuk melihat parameter-parameter mana yang paling berpengaruh terhadap nilai Basic Reproduction Ratio atau $R_{0}$. Dari hasil analisis sensitivitas diperoleh parameter yang cukup berpengaruh terhadap nilai $R_{0}$ adalah parameter $p_{j} \operatorname{dan} f$. Hasil analisis sensitivitas ditunjukkan pada gambar 3 berikut ini.

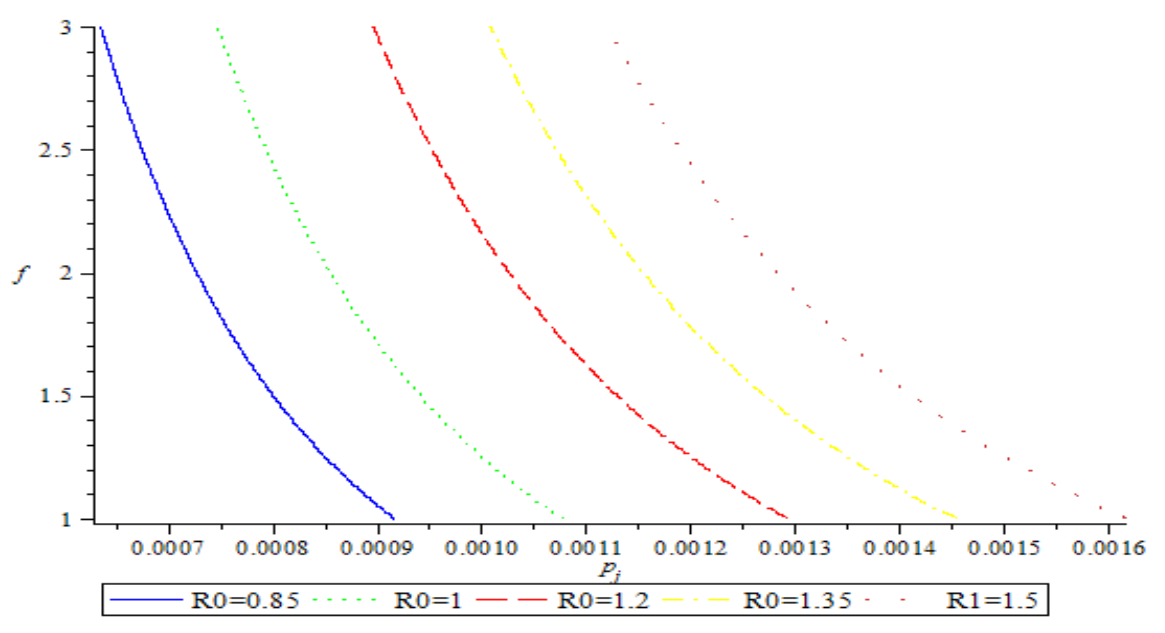

Gambar 3. Analisis Sensitivitas

Dari gambar 3 dapat dilihat bahwa semakin besar nilai parameter $p_{j}$ dan $f$ maka nilai $R_{0}$ juga menjadi semakin besar. Artinya semakin besar frekuensi menyuntik yang dilakukan pengguna narkoba dan semakin besar peluang sukses infeksi dari jarum terinfeksi ke pengguna narkoba susceptible maka akan meningkatkan nilai $R_{0}$ sehingga ketika $R_{0}>1$ endemik akan terjadi. 


\section{SIMPULAN}

Adapun kesimpulan dari hasil penelitian ini adalah:

1. Model matematika penyebaran HIV/AIDS pada pengguna narkoba melalui jarum suntik adalah:

$$
\begin{aligned}
& \frac{d S}{d t}=B-f p_{j}\left(\frac{J_{i}}{J_{s}+J_{i}}\right) S-\mu S . \\
& \frac{d E}{d t}=f p_{j}\left(\frac{J_{i}}{J_{s}+J_{i}}\right) S-(\mu+\alpha) E . \\
& \frac{d I}{d t}=\alpha E-(\mu+\beta) I \\
& \frac{d A}{d t}=\beta I-(\mu+\gamma) A . \\
& \frac{d J_{s}}{d t}=\rho f(S+E+I)-f p_{h} I\left(\frac{J_{s}}{J_{s}+J_{i}}\right)-\theta J_{s}-\omega \rho f I . \\
& \frac{d J_{i}}{d t}=\omega \rho f I+f p_{h} I\left(\frac{J_{s}}{J_{s}+J_{i}}\right)-\theta J_{i} .
\end{aligned}
$$

2. Diperoleh dua titik kesetimbangan yaitu titik kesetimbangan bebas penyakit dan kesetimbangan endemik. Titik kesetimbangan bebas penyakit yaitu $D F E=$ $\left(S=\frac{B}{\mu}, 0,0,0, J_{S}=\frac{\rho f B}{\mu \theta}, 0\right)$ dan titik kesetimbangan endemik adalah sebagai berikut:

$$
\begin{aligned}
& S^{*}=\frac{\left(\rho \mu+\rho \beta+\rho \alpha+p_{h} \alpha\right) B}{\alpha\left(p_{h} \mu+p_{h} f p_{j}-\rho \beta+\rho \omega f p_{j}\right)} \\
& E^{*}=\frac{\left(B\left(-\rho \mu^{2}-\rho \mu \beta-\rho \alpha \mu-\rho \alpha \beta+\rho \omega f \alpha p_{j}+p_{h} f \alpha p_{j}\right)\right)}{\left(\left(p_{h} \mu^{2}+p_{h} f p_{j} \mu+\mu p_{h} \alpha-\rho \mu \beta+\rho \omega f p_{j} \mu+\rho \omega f \alpha p_{j}+p_{h} f \alpha p_{n} \alpha \beta\right) \alpha\right)} \\
& I^{*}=\frac{B\left(-\rho \mu^{2}-\rho \mu \beta-\rho \alpha \mu+\rho \omega f \alpha p_{j}+p_{h} f \alpha p_{j}-\rho \alpha \beta\right)}{p_{h} \mu^{3}+a_{1} \mu^{2}+a_{2} \mu+\rho \omega f \alpha p_{j} \beta-\rho \alpha \beta^{2}+p_{h} f \alpha p_{j} \beta} \\
& A^{*}=\frac{\beta B\left(-\rho \mu^{2}-\rho \mu \beta-\rho \alpha \mu+\rho \omega f \alpha p_{n}+p_{h} f \alpha p_{j}-\rho \alpha \beta\right)}{\left(p_{h} \mu^{3}+a_{1} \mu^{2}+a_{2} \mu+\rho \omega f \alpha p_{j} \beta-\alpha \beta^{2}+p_{h} f \alpha p_{j} \beta\right)(\mu+\gamma)} \\
& J_{S}^{*}=\frac{\left(B\left(p_{h} \mu^{2}+a_{3} \mu+a_{4}\right) \rho^{2}\left(\mu^{2}+\left(\alpha+f p_{j}+\beta\right) \mu+\alpha f p_{j}+\alpha \beta-\omega f \alpha p_{j}+p_{j} f \beta\right)\right)}{\left.(\mu+\gamma)(\mu+\beta) a_{5} \theta p_{j}\left(\rho \mu+\rho \alpha+\rho \beta+p_{h} \alpha\right)\right)}
\end{aligned}
$$




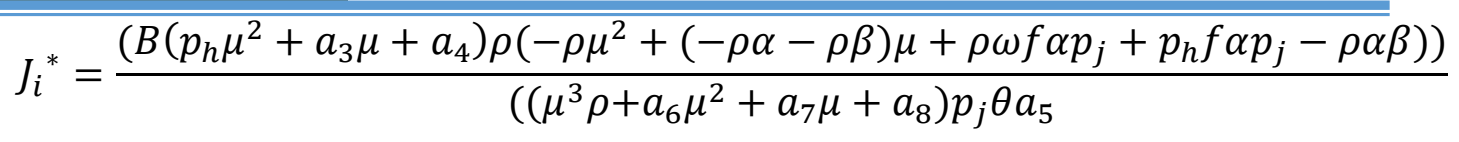

Dimana,

$$
\begin{aligned}
& a_{1}=p_{h} f p_{j}+p_{h} \alpha-\rho \beta+p_{h} \beta+\rho \omega f p_{j} \\
& a_{2}=\rho \omega f \alpha p_{j}+p_{h} \alpha \beta+p_{h} f \alpha p_{j}-\rho \alpha \beta+p_{h} f p_{j} \beta+\rho \omega f p_{j} \beta-\rho \beta^{2} \\
& a_{3}=\rho \omega f p_{j}+p_{h} f p_{j}+p_{h} \beta+p_{h} \alpha \\
& a_{4}=p_{h} f \alpha p_{j}+\rho \omega f p_{j} \beta+\rho \omega f \alpha p_{j}+p_{h} f p_{j} \beta+p_{h} \alpha \beta \\
& a_{5}=p_{h} \mu+p_{h} f p_{j}-\rho \beta+\rho \omega f p_{j} \\
& a_{6}=2 \rho \alpha+2 \rho \beta+p_{h} \alpha \\
& a_{7}=p_{h} \alpha \beta+3 \rho \alpha \beta+\rho \beta^{2}+\alpha^{2} \rho+p_{h} \alpha^{2} \\
& a_{8}=p_{h} \alpha^{2} \beta+\rho \alpha \beta^{2}+\alpha^{2} \rho \beta
\end{aligned}
$$

Eksistensi titik kesetimbangan endemik terpenuhi ketika,

$$
\frac{\rho \omega f \alpha p_{j}+p_{h} f \alpha p_{j}}{\rho \mu^{2}+\rho \mu \beta+\rho \alpha \mu+\rho \alpha \beta}>1
$$

3. Diperoleh nilai Basic Reproductive Ratio $\left(R_{0}\right)$ yang dinyatakan dalam bentuk berikut:

$$
R_{0}=\sqrt[3]{\frac{\alpha p_{j} f\left(\rho \omega+p_{h}\right)}{(\mu+\alpha) \rho(\mu+\beta)}}=\sqrt[3]{\frac{\rho \omega f \alpha p_{j}+p_{h} f \alpha p_{j}}{\rho \mu^{2}+\rho \mu \beta+\rho \alpha \mu+\rho \alpha \beta}}
$$

4. Dari hasil simulasi numerik diperoleh dinamika laju perubahan tiap populasi pada model sedangkan dari hasil analisis numerik diperoleh bahwa parameter yang cukup berpengaruh terhadap nilai $R_{0}$ adalah parameter $p_{j}$ dan $f$. Semakin besar frekuensi menyuntik yang dilakukan pengguna narkoba dan semakin besar peluang infeksi dari jarum terinfeksi ke pengguna narkoba susceptible maka akan meningkatkan nilai $R_{0}$ sehingga ketika $R_{0}>1$ endemik akan terjadi

\section{DAFTAR PUSTAKA}

Departemen Kesehatan RI., Departemen Kesehatan Republik Indonesia, http://www.depkes.go.id/, diakses 30 Oktober 2019. 
Diekmann O., Heesterbeek J.A.P., Roberts M.G. 2009. The Construction of Next Generation Matrix For Compramental Epidemics Models. Journal of The Royal Society Interface, 7:873-885.

Pusat Data dan Informasi Kementerian Kesehatan RI (InfoDATIN). 2014. Situasi dan Analisis HIV AIDS.

Ram Naresh, Agraj Tripathi, Dileep Sharma. 2011. A nonlinear AIDS epidemic model with screening and time delay. Applied Mathematics and Computation 217(9): 44164426.

Setiawaty dkk. 2013. Analisis Kestabilan Pada Model Penyebaran Hiv/AIDS Di Kota Palu. Jurnal Ilmiah Matematika dan Terapan Vol.10 No.1 Hal 74-82.

Triska dan Gusriani. 2016. Analisis angka reproduksi dasar model matematika penyebaran HIV melalui jarum suntik pada populasi pengguna narkoba. Jurnal Matematika Integratif. Vol.12 No.1 hal 59-66 